This item was submitted to Loughborough's Research Repository by the author.

Items in Figshare are protected by copyright, with all rights reserved, unless otherwise indicated.

\title{
World cities under conditions of financialized globalization: towards an augmented world city hypothesis
}

\section{PLEASE CITE THE PUBLISHED VERSION}

https://doi.org/10.1177/0309132514558441

\section{PUBLISHER}

SAGE Publications $@$ The Authors

\section{VERSION}

AM (Accepted Manuscript)

\section{PUBLISHER STATEMENT}

This work is made available according to the conditions of the Creative Commons Attribution-NonCommercialNoDerivatives 4.0 International (CC BY-NC-ND 4.0) licence. Full details of this licence are available at: https://creativecommons.org/licenses/by-nc-nd/4.0/

\section{LICENCE}

CC BY-NC-ND 4.0

\section{REPOSITORY RECORD}

Bassens, David, and Michiel Van Meeteren. 2019. "World Cities Under Conditions of Financialized Globalization: Towards an Augmented World City Hypothesis”. figshare. https://hdl.handle.net/2134/37048. 


\section{World cities under conditions of financialized globalization: Towards an augmented world city hypothesis}

David Bassens ${ }^{a}$, Michiel van Meeteren ${ }^{b}$

a Department of Geography, Vrije Universiteit Brussel (VUB), Pleinlaan 2, B-1050 Brussels Belgium, david.bassens@vub.ac.be, +32-2-629 3382

b Department of Geography, Ghent University, Krijgslaan 281 (S8), 9000 Ghent - Belgium, michiel.vanmeeteren@ugent.be, +32-9-264 4697

\section{Paper forthcoming in Progress in Human Geography.}

\section{Abstract}

This paper interrogates the enduring, yet changing role of world cities as centers of capitalist command and control amidst deepening uneven development. By incorporating financialization processes in Friedmann's (1986) world city hypothesis, we hypothesize that the world city archipelago remains an obligatory passage point for the relatively assured realization of capital. The advanced producer services complex appropriates superprofits as producers of coconstitutive knowledge on operational and financial firm restructuring, the creation of new circuits of value, and capital switching. Geographically, beyond the International Financial Center shortlist, the wider world city archipelago inserts finance capital (logics) in contemporary economies and societies.

\section{Keywords: World Cities, Financialization, Advanced Producer Services, Overaccumulation, Financial Crisis, International Financial Centers}




\section{World cities under conditions of financialized globalization: Towards an augmented world city hypothesis}

\section{World cities: Continuity and change}

The durability of the economic woes that erupted with the financial meltdown of 2008 challenge ideas of worldwide market-led economic convergence and invite a focus on the mechanisms that (re)produce geographies of uneven development (Aalbers, 2009; Engelen and Faulconbridge, 2009; Harvey, 2014). A recurring theme in these uneven geographies is the unmistakable metropolitan dimension in terms of the crisis' origins, manifestations, and remedies. While the crisis reaches deeply in terms of societal depth and geographical range, some places matter more to our understanding of its genesis than others (Clark, 2005). In terms of origins, New York and London, but also many other densely interconnected urban areas across the globe were crucial cogs in the production and spread of the crisis (French et al., 2009; Wainwright, 2012; Wójcik, 2013a). It was here that large bank defaults and massive temporary lay-offs first manifested themselves after the crisis commenced, even though the imminent default surge quickly expanded beyond the toxic-asset pools buried beneath the pinnacles of finance (Bassens et al., 2013a; Derudder et al., 2011). Since then, it have been the very same localities that are re-positioning themselves as candidates for post-crisis growth regimes (Engelen and Glasmacher, 2013). Metropolitan centers and the practices within them remain essential components of any analysis of the contemporary capitalist order of which the financial crisis was a direct product (Sassen, 2010).

Comprehending capitalism from the perspective of metropolitan centers is all but novel. At least since the 1980s, the world cities research tradition has explicitly and critically analyzed the 
spatial organization of global capitalism from the vantage point of networked city localities (Friedmann and Wolff, 1982; Friedmann, 1986). More recently, world cities research has increasingly understood the global economy's spatial organization as an archipelago of world cities (Taylor, 2004). This conceptualization, based on the notion of a flow-centered metageography, captures interurban interconnections that undergird the global economy (Beaverstock et al., 2000; Taylor, 2004; cf. Lewis and Wigen, 1997), which cannot be reduced to constituent national economies (Sassen, 1991 [2001]). The networked perspective invoked a lively empirical debate about the actual geographical articulation or 'footprint' of the world city archipelago (WCA) and its backbone of International Financial Centers (IFCs) in the past decade. This has occurred either through ever more sophisticated determinations of its most relevant 'islands' and connections (Derudder et al., 2010) or challenging where the boundaries of the archipelago space lie (Bassens et al., 2010; Lai, 2012). The overall consensus is that capitalist 'command and control' is exercised from a limited set of cities which function as nodes for transnational flows of capital, goods, people, and information from which actors operating from these places draw their power (Allen, 2010; Parnreiter, 2014). Accepting the more or less agreed-upon geographies of the WCA, this article sets out to meet the challenge of revisiting the question of what goes on in WCA space. Such an analytical exercise can be performed on at least two levels of abstraction. One can engage in a metatheoretical exercise envisioning the WCA as an abstract networked unity that performs a certain, yet to be defined, part in contemporary capitalism (Castree, 1999). Alternatively, the internal differentiation of the WCA could be the focus, where one details the role of (sets of) particular cities. The ambition of this paper is to take the former course of action, where as a mode of exposition we choose to augment Friedmann's (1986: 89) original world city hypothesis; not to retrospectively debate its 
validity at the time of conception, but to attempt to adapt the thesis to contemporary conditions of financialized globalization.

Friedmann (1986) conceptualized 'world cities' as key basing points of capital from where the escape of the labor market rigidities of the 1970s crisis were orchestrated, while retaining capital accumulation in the world's economic core areas. The related work on 'global cities' (Sassen-Koob, 1982, 1985; Sassen, 1991 [2001], 1998) theorized places where global control functions are produced by Advanced Producer Services (APS) in accountancy, advertising, finance, law, and management consultancy. Following Parnreiter (2013), we take Friedmann's definition of world cities to stand very close to Sassen's global city concept as both examined the same processes in the same places in the same era. Expanding these pioneering works, an augmented world city hypothesis has to address the different nature of the current crisis compared to the one of the 1970s. Both crises can be considered as different expressions of a general crisis of overaccumulation, even though the barriers to capital realization are currently very different (Harvey, 2010). Following Marx (1894[1991]), Harvey (1982[2006]: 192) defines overaccumulation as a state of over-production of capital when the 'capitalists' necessary passion for surplus-value-producing technological change, when coupled with the social imperative 'accumulation for accumulation's sake', produces a surplus of capital relative to opportunities to employ that capital.' As Harvey (2010: 64) notes, the crisis of the 1970s was characterized by a profit squeeze in the context of stagflation, whereas the recent crisis shows capitalism's flipside expressed in overproduction facing a lack of effective demand in established circuits of value (Harvey, 2010: 65-66, 116). Following the arguments of Harvey (2010, 2014) and Arrighi (1994[2010]), we expect the increasing importance of financial capital 
circuits - i.e. financialization - and rent-seeking behavior (Harvey, 2014) to change the character of command and control functions exercised from world cities.

While still functioning as a space from where global production is coordinated to an important degree, we argue that these practices related to command and control have been subsumed in a logic of financialization, making that the world city archipelago constitutes an obligatory passage point for the relatively assured realization of capital under conditions of financialized globalization (cf. Allen, 2010). The rise of global financial markets has increased the global level of uncertainty about capital realization to such an extent that APS in world cities - as providers of the necessary and seemingly sufficient authority and expertise - collectively hold a feeearning 'class monopoly' that yields 'class monopoly rents' (Harvey, 1974). Such an augmentation blurs differences between world cities research and financial geography since the social processes and associated geographies overlap significantly (Coe et al., 2014; Sassen, 2010; Wójcik, 2013b). Yet, at the same time, it is overly reductionist to collapse the more extensive geography of the WCA onto a concise network of IFCs. Typologically, whereas all IFCs are world cities, the WCA does greatly extend beyond that shortlist because, as we shall extensively argue below, APS practices relating to the worlds of finance and production have increasingly become interdependent.

The paper is organized as follows. Section two will review the evolving political-economic context in which world city research operated since the 1980s and describes associated changes in command and control. Section three sets up the theoretical apparatus to incorporate financialization in the world city hypothesis. By analyzing the hazards of capital accumulation under the current round of overaccumulation it elucidates the practices and interactions among 
APS firms and their clients that help reproduce the geography of world cities. We subsequently discuss how this relates to understandings of the financial crisis of 2008. The paper concludes with suggestions for how empirical research on the WCA could be informed by, and simultaneously corroborate, this augmented world city hypothesis.

\section{The changing mode of command and control in world cities}

The defining feature of world cities - at least from its political-economy perspective that originates with the work of Stephen Hymer (1972) and that became famous through John Friedmann and Goetz Wolff (1982, see Parnreiter, 2013; Surborg, 2011 for recent historical overviews) - is their role as 'basing points' for global capital from which 'command and control' is exercised over capitalist accumulation (Friedmann, 1986; Hymer, 1972; Sassen 1991[2001])i. Although world city research has more recently been focused on the geography of the archipelago of world cities and its interrelations (Taylor, 2004), the notion that capitalist command and control defines the research object has been broadly maintained (Saey, 2007; Surborg, 2011; Parnreiter, 2013, 2014). However, not all scholars accept the relation between command and control and world cities uncritically. Criticisms cover two broad topics. First, command and control has been argued to be too crude a notion to specify the relation between world cities and the exercise of power and therefore needs unpacking (Allen, 2003, 2010; Jones, 2002; Thrift, 1993). John Allen (2003: 5) convincingly makes the case in this respect that we have to 'clearly distinguish between the exercise of power and the resource capabilities mobilized to sustain the exercise'. Interpreting Allen (2003: 108, 112, 152-157), it is the assemblage of resources and abilities accessible from the WCA that enables command and control in world cities, leaving the actual exercise of that power a contingent matter. For Allen (2010: 2898, building on Callon, 1986), world cities constitute an 'obligatory passage point' for 
particular business practices 'to work'. Its micro-foundations are built on the practices of financial and business elites in the WCA that involve modes of power such as manipulation, seduction or inducement other than top-down domination and control (Allen, 2010; Jones, 2002). This revision of command and control informs the analysis developed hereafter (cf. Saey, 2007) and is illustrative of how analytical strategies informed by poststructuralist perspectives can illuminate aspects of time-tested debates regarding the workings of capital in new ways (cf. Berndt and Boeckler, 2010; Jones, 2008).

Second, the contingent nature of the exercise of power on the micro-level has led some authors to question the validity of the claim that command and control define world cities on the macrolevel (Smith and Doel, 2010; Thrift, 1993) up to the point of calling the existence of command and control in world cities a myth (Smith, 2014). The central tenet of this conviction is that capitalism has changed so profoundly in the last decades due to the rise of finance and its associated complexity that it is essentially 'uncontrollable' (Thrift, 1993: 232), as is taken to be exemplified by the erratic, volatile, and crisis-prone nature of the global financial system (Smith, 2014: 104). For Thrift, ongoing concentration in world cities should primarily be explained from their role as 'sites of social contact and narrative innovation, as places where this new world presents and represents itself, as places for storytelling rather than strategy' (Thrift, 1993: 233). Whereas the processes in world cities have changed substantially, we see no evidence to conclude that the notion of command and control - as conceptualized above - is a myth. Rather, we argue, current modes of command and control seem to come to a crucial extent with the ability of agents in world cities to produce 'strategic narratives' (Christophers, 2009; Froud et al., 2006; Hall, 2006) which rely to a significant degree on storytelling to make the crisis-prone global financial system legible, but which also involves circumscribed expertise of the specific 
APS trade. For instance, as is evident in offshoring, law firms and investment banks have a set of standard or customized solutions on offer that allows clients to circumvent tax regulations (e.g. Wainwright, 2011). The enduring concentration of command and control in world cities and its qualitative changes under financialization then become a crucial conundrum to disentangle.

To understand this shifting emphasis in the modality of command and control it is helpful to revisit the changes in the political-economic context from the crisis of the 1970s and 1980s onwards. We identify three epochs in particular, which exemplify distinct dominant practices of command and control that morphed into one another. When Friedmann and Wolff (1982) first articulated their world city hypothesis they had a very specific goal in mind. By the 1980 s it had become clear that the world economy had found ways out of the crisis of Fordism that had ravaged the 1970s. Culminating with the Volcker Shock, a decade of massive capital shortage in core economies like the US had gradually been reversed as a consequence of the massive transnationalization of global financial capital flows (Christophers, 2013; Krippner, 2010) enabling large transnational corporations (TNCs) to readjust their global capital outlay. Part of this readjustment was an increased globalization of industrial capital as labor-intensive production was being offshored to the 'periphery' to reap the benefits of low skilled nonunionized cheap labor while the same corporations divested their production plants in the 'core'; a process that was labeled the 'New International Division of Labor (NIDL) (Fröbel et al., 1977 [1980]; Hymer, 1972). World city scholarship of the early 1980s, such as Cohen (1981), Friedmann and Wolff (1982), Ross and Trachte (1983), and Sassen-Koob $(1982,1985)$ was concerned with the spatiality of the causes and consequences of these developments. Centralization of capital in the core while production was offshored to the periphery posed a coordination problem. This spatial division of labor had to be conducted in a global institutional 
context that was not yet optimized for global capital and yielded a significant amount of labor for highly-educated service work in the world's best connected places, world cities, to alleviate transaction costs. The fact that TNCs were actually making huge profits globally in the midst of local deindustrialization gave rise to case-based scholarship on these issues (e.g. Massey, 1984 [1995]; Soja et al., 1983). Control in this context meant literally 'control over assets stretched over space': How could a global production process be organized with the cheapest possible labor inputs while repatriating the profits to the corporate headquarters?

Even in the early 1980s, the debate was embroiled by notions of 'the rise of a service economy' and 'the coming of postindustrial society' (Bell, 1973). However, more complicated socio-spatial configurations were also emerging that could not be explained by the somewhat crude 'capital seeks cheapest labor' arguments of the NIDL thesis (see Henderson and Castells, 1987; Ross and Trachte, 1990). Silicon Valley (e.g. Saxenian, 1996) and the Japanese Toyotism model (Schoenberger, 1997) were examples of capitalist growth regimes based on relative surplus value realization that could retain their 'local embeddedness'. Regional economies could be competitive by specializing in sophisticated production processes that were difficult to replicate elsewhere (Storper and Walker, 1989, cf. Tickell and Peck, 1992). Innovative regions within these competitive flexible production systems could then utilize their comparative advantages in the trade system of a new regional world (Scott, 1998; Storper, 1997), all made possible by the new technologies that powered the 'rise of the network society' (Castells, 1996 [2000]). Importantly, this regional narrative of flexibility had its counterpart in changes to how control was exercised within large corporations. During the 1980s, corporate governance had gradually transformed from a hierarchical portfolio organization under managerial control (central in Hymer, 1972) to flexible organizations dominated by a shareholder value regime (Fligstein, 
2001). Once initiated, these organizational forms and strategies gradually became omnipresent across industrial fields through organizational mimicry (DiMaggio and Powell, 1983). These evolutions were also crucially mediated by the state: The decision in 1981 by the Reagan administration to relax antitrust laws, which until then stymied large mergers and acquisitions, raised the relevance of their stock market performance (Fligstein, 2001: 156). Moreover, in a context of progressive financial deregulation and an emerging new international financial system (Thrift and Leyshon, 1988), TNC reorganizations also involved rerouting capital through IFCs like London (Burn, 1999) and offshore financial centers (Roberts, 1995), which since long had served their purpose in Eurobond markets. Even if the outcomes were far from premeditated (Krippner, 2010), one can appreciate that financial and industrial capital deregulations allowed reaffirmation of US hegemony despite falling profit rates in industry permitting a new growth regime based on the massive import of foreign capital (Arrighi, 1994[2010]; Harvey, 2003).

World cities seemed to fit into the new postfordist growth theory as they were theorized as sites hosting command and control functions that served as alleviators of transaction costs barring the realization of the comparative advantages of the new regional world. Services were interpreted to lubricate the process of flexible specialization in a globalizing economy that became increasingly interconnected through information technology (see Daniels and Moulaert, 1991; Knox and Taylor, 1995; Moulaert et al., 1997). Collectively, APS could be regarded as just another regional specialization as control functions were gradually being externalized to independent APS TNCs that themselves were subject to agglomeration economies in world cities (Coffey and Bailly, 1990) acting as 'neo-Marshallian nodes in 'global networks' (Amin and Thrift, 1992; Brenner 1998; Sassen, 1991 [2001]). Sassen (1988, 1991 [2001]) introduces the term 'Advanced Producer Services complex' (henceforth APS complex) to express this 
specialized and collective role of APS in the world economy. Yet, it was acknowledged that APS differed from other regional specializations by having a seemingly indispensable function for the others, namely that of providing 'global control capability' (Sassen-Koob, 1985; Sassen, 1991 [2001]). Operational efficiency through flexibility implied an increased focus on the return on capital of the firm. Thus, firms aiming for shareholder value were drawn to optimize these efficiency metrics as they became more important for investors to gauge and compare firms' operational performance. Apart from assisting TNC in optimizing and making more flexible their supply chains, APS firms played an important role in the codification and implementation of these metrics as well (Froud et al., 2000, 2006).

This emphasis on world cities as particular regional specialization received significant criticism, since it works to naturalize highly unequal power relations, while covering up proactive state policies and subsidies that support world city formation (Massey, 2007). Nevertheless, the postfordist discourse of innovative regional specialization as a growth model remains dominant, albeit contemporarily subsumed in discourses regarding a 'knowledge based economy' (e.g. Rodrigues, 2002) or the 'cognitive-cultural economy' (Scott, 2012: 11). Innovation persists to be an important competitive strategy to achieve capital accumulation (Scott, 2012; Storper and Walker, 1989). However, in an effective demand crisis it is highly unlikely to be sufficient to achieve a sustainable three percent worldwide compound growth path (Harvey, 2010, 2014). Therefore, we expect that other capital accumulation strategies such as expansion in space through processes associated with globalization - and time - through credit - have become increasingly important as the world slid into a crisis of overaccumulation (Arrighi, 1994 [2010]; Harvey, 1982 [2006], 2010). Moreover, research on geographies of innovation processes and scientific knowledge production (Asheim et al., 2007; Saxenian, 2007) suggest that the 
relationship between geographies of world cities and innovation is often ambiguous. Accountants, lawyers and bankers might play a role in commodifying inventions, but they are not very likely to be at the heart of the matter, although APS narratives aim to make clients believe the contrary (Engelen et al., 2010a). In fact, multinationals relocating to world cities often tend to leave their research and development departments at their old location (Baaij et al., 2004; Muellerleile, 2009). These remarks caution against a too direct association between APS firms and development in a knowledge-based economy. If less fundamental to innovation, then, where does that leave the meaning of command and control produced in world cities?

Here we hypothesize that financialization dynamics require continued and accelerated agglomeration in world cities beyond the IFC shortlist as clients are in dire need for services that allow indirect control over financial assets. While financialization entails a wide set of processes (Engelen, 2008), it can generally be understood as the growing relevance of financial motives, financial markets and financial institutions in the operation of domestic and international economies (Epstein, 2005). First evidence is already abundantly in place: World cities have been shown to be involved in practices of territorial and financial arbitrage (Sassen, 2006; Wainwright, 2011; Wójcik, 2013a, 2013b). Furthermore, the shareholder value mode of control has led to radically different corporate strategies making corporations dependent on APS as market intermediaries (Folkman et al., 2007) to maneuver in global financial markets (Froud et al., 2006; Lee et al., 2009). Beyond the attraction of capital in primary markets, firms are directly influenced by the trading of their equity or debt in secondary markets which in turn strongly influences the possibility of raising capital in the primary market. This development has necessitated the deployment of a range of APS for the financial optimization of industrial corporations bringing along all kinds of consequences for how the firm produces adequate 
'numbers' (i.e. value of stocks, return of investment) for shareholders and projecting strategic 'narratives' for external and internal consumption (Froud et al., 2006; O'Neill, 2001). These developments further drive the need for services that aid the rationalization of actual production and the optimization of the surplus, and secure a 'credible' and 'creditworthy' profile. Lastly, the deepened implementation of financial logics in post-welfare states, for instance through massive privatized pension schemes (Boyer, 2000; Clark, 2003; French et al., 2011; Hall, 2012), but also through state strategies that fuel world-city formation as growth strategy (Harvey, 1985; Massey, 2007; Olds and Yeung, 2004), are likely to augment and deepen command and control functions in world cities. Taken together, these three developments suggest financialization processes are not just emanating from practices taking place in mainstay IFCs, but are introduced more deeply into wider economies by APS operating from a much broader set of world cities.

\section{World cities as obligatory passage points under financialized globalization}

\section{The emergence of an APS class monopoly due to overaccumulation}

In order to understand the enduring relevance of world cities for command and control over capital we have to delve into the specific role that the APS complex plays in the valorization and realization of capital in the context of financialization. We construct that argument by drawing on the conceptual apparatus of historical-geographical materialism (Harvey, 1982 [2006], 2010). We start our inquiry with the central axiom that contemporary capitalism is increasingly characterized by a state of overaccumulation of capital that is the root cause of the increasing prevalence of economic crises (Arrighi, 1994 [2010]; Harvey, 2010). 'Capital' is a process of value in motion: Money capital is brought into a circulation process consisting of a combination of constant and variable capital that eventually allows for the realization of its initial value and a 
surplus. This necessarily implies the consumption of a use value of some sorts (Marx, 1885 [1992]). The lag between the initial capital layout and the moment of final consumption, and therefore the ultimate realization of surplus value, can be stretched across space and time. Until this moment of realization, capital has to be regarded as 'fictitious' since it is unknown whether or not it will finally realize itself: an investment can fail (Marx, 1894 [1991]: 594-606; cf. Harvey, 1982 [2006]: 267). In order for capital to reproduce itself and expand there have to be enough investment opportunities to realize surplus value. And these opportunities have to be orchestrated by socially constructing material circuits of value (Lee, 2006, 2011). Switching capital between these various circuits involves significant transaction costs which function as barriers to capital and surplus realization and a source of crises (Harvey, 1982 [2006]).

The alleviation of these transaction costs is generally considered one of the important functions of the financial system, which collects a fee in return (Strange, 1988 [1994]). In absence of overaccumulation, one could argue that the APS complex serves to alleviate transaction costs and thereby make markets more efficient: It is through the labor of the APS complex that valorizations of capital come into existence that otherwise would not have occurred (Bryson et al., 2004; Christophers, 2013; Walker, 1985). However, in a period of overaccumulation these transaction costs acquire a new character. During overaccumulation there is 'a situation where there is excess capital relative to the opportunities to use capital profitably' (Harvey, 2010: 45), otherwise known in financial circles as the 'wall of money' problem (cf. Engelen et al., 2010a, 2011). Inevitably, some capital will not realize itself and will hence be devalued or destroyed. This generates a fundamental uncertainty about the profitability of capital. Consequently, capitalists who are better informed about which segments of capital will eventually realize themselves with a surplus, will incur a lower uncertainty than others. Lower uncertainty does not 
imply calculated risk, and therefore participating in the capital allocation game on the basis of lower uncertainty is still an unpredictable affair (cf. Engelen et al., 2010a; Wainwright, 2012). However, if this knowledge about lower uncertainty is derived from a structural dominant position in circuits of value, it allows the actor to sell 'relative certainty of capital realization' for a fee, offloading the risk of the actual investment to the client. This fee is essentially a form of rent, since it is incurred regardless of capital realization (Mandel, 1972 [1975]: 192; Marx, 1894 [1991]: 785; Walker, 1974). These surplus- or superprofits (Marx, 1894 [1991]) will not dissolve as long as there is overaccumulation combined with knowledge asymmetries about potential surplus value realization.

The 'structural dominant position in circuits of value' from which these knowledge asymmetries are derived, is not the exclusive property of one single actor, but emerges from the combined activities of a class of actors (Swyngedouw, 1992). As an abstract category, the APS complex holds exactly such a position under the current conditions of overaccumulation. Collectively, the APS complex forms a 'class monopoly' as their collective knowledge resources allow the appropriation of class-monopoly-rent (Harvey, 1985: 65). This 'class-monopoly rent describes a situation in which the rate of return to a class of providers of a [...] resource [...] is set by the outcome of conflict with a class of consumers of that resource' (Harvey, 1974: 239)ii. Whether that rent is actually incurred by the class-monopoly is contingent on the socio-spatial relations within the APS complex. The APS class monopoly involves a strong spatial expression, since its underlying structural dominant position in circuits of value draws on a network of localization economies where the right combination of people and information can be converted into knowledge about potential surplus generation (Amin and Thrift, 1992; Taylor, 2000). The effects of this localization economy reverberate throughout the cities that form its main nodes and 
provide it with structured coherence (Harvey, 1985: 125-164, 2005 [2006]: 102-103), as urban land and labor markets, politics and growth regimes tend to co-evolve with the prevalent accumulation logic. The system of interconnected localization economies reveals itself as the particular geography of the WCA (Taylor, 2004), while the salience of this structured coherence can be observed in its main nodes (Sassen, 1991 [2001]; Massey, 2007; Lizieri, 2011). The notion of 'class monopoly' should, however, not be confused with the class distinction that stems from the organization of production and the division of labor (Harvey and Chatterjee, 1974: 36). Neither does a class monopoly imply that the APS complex has to be considered a unitary actor, as different actors within the monopoly alternately cooperate and compete for their piece of the pie (Harvey, 1974, 1985). The existing literature on APS firms under globalization discusses how a variety of socio-spatial practices, which crucially depend on face-to-face contact and tacit knowledge transfer, are deployed to manage knowledge across borders (e.g., Beaverstock, 2004; Morgan, 2001; Morgan and Quack, 2006). These strategies range from temporary detachments and expatriation to the development of transnational business communities both inside and outside the firm. The community concept suggests transnational social groups that hinge on a common set of business and media sources and a shared institutional space for professional education (Hall, 2009). Notwithstanding internal strife, then, the exploitation of this class monopoly relies on a shared interest of the complex that can resembles a fraction of capital (cf. Jessop, 2000). This is a situation of oligopoly that Schumpeter (1928) called 'correspective competition' and was explicitly attributed to the financial sector and its sustained high profits just prior to the crisis (Crotty, 2008: 170). In the context of world city research, a similar argument of capitalists actively attempting to subdue market competition by establishing an anti-market monopoly position was first brought up by Braudel (1982) and was elaborated by Arrighi, (1994 [2010]: 10, 21) and Taylor (2000). 


\section{Class monopoly exploitation and reproduction through APS practices}

Having reasoned the emergence of the APS class monopoly in an abstract way, this section theorizes the associated command and control position from the practices within the APS complex in the WCA that exploit and reproduce that position. In our view, the APS complex' class monopoly emerges from the interplay of three distinct processes or 'elements' at the juncture of conceptual spaces of production and finance (Figure 1). These conceptual spaces can be understood through the various moments of capital in the accumulation process; i.e. the classical M-C-M' formula, Marx (1867 [1976], 1885 [1992]) that can be disaggregated and spatialized (Lee, 1989). Four distinctive moments in such a circuit of value can be identified that elucidate the functions of command and control: (i) the origination/pooling of capital (M), (ii) the transformation of respectively capital into commodities (M-C) and (iii) commodities into expanded capital (C-M'), and (iv) the optimization and 'multiplication' of the surplus (M'). This formula can be read in terms of two ideal-type spaces: production space typifies the industrial and commercial circuits of capital, which are driven by the maximization of capital accumulation through the process of finding the optimal combination of labor and capital in production on the one hand and allocation to the most profitable markets on the other. The modus operandi of this space has been greatly influenced by the challenges and opportunities of globalization in terms of coordinating global production (Henderson et al., 2002). Financial space, on the other hand, explains capital accumulation through the maximization of returns on credit that - even if only in the very last instance - has been extended to the production circuit (Labban, 2010). The workings of financial space itself have profoundly changed by the globalization and virtualization of financial markets and the growing proliferation and trading of debt products and derivatives. Both spaces ultimately reflect perspectives, or 'windows', on the same process of capital 
circulation (Marx, 1885 [1992]). Both spaces also crucially depend on knowledge-producing practices by the APS complex that drives a clear-cut tendency towards the further agglomeration and urbanization of capital in world cities (Krätke, 2014; Sassen, 1991 [2001]).

$<$ Insert figure 1 about here>

The crucial and self-reinforcing role that the APS complex plays, draws on the three elements that intertwine financial and production space under financialized globalization. The first element emerges from the aggregation of service interventions in the production space. The second element is related to the social construction of material circuits of value (Lee, 2006). The third element relates to enabling capital switching. These elements are not a-priori connected to specific actors and these elements can be found in endless different configurations of roles divided among several actors within the APS complex. However, each element thrives on the two others. Let us take each element in turn.

First, APS attain a favorable knowledge asymmetry vis-à-vis the production space through consecutive rounds of service provision in the context of financialization. Generally, world cities research has mostly focused on $\mathrm{M}-\mathrm{C}$ and $\mathrm{C}-\mathrm{M}$ ' transformations in conceptualizing the roles of the APS complex, leaving the $\mathrm{M}$ and $\mathrm{M}$ ' moments and the 'abridged' M-M' circuit (Marx, 1894[1991]: 515-524) to specialized research on financial centers (Pryke and Lee, 1995; Thrift and Leyshon, 1994). The APS complex still provides knowledge about how to organize production (the M-C transformation) and help orchestrate demand for the produced commodities and support their actual sale (the C-M' transformation). Knowledge about consumer preferences, sensitivities, and susceptibilities is provided by advertising agencies, 
while a range of legal, accountancy, and financial services tackle effective demand problems by providing consumer credit (Froud et al., 2006). But the APS complex is also strongly implicated in the two other moments of capital, M and M'. To secure the inflow of capital into the circuit, firms will hire investment bankers and lawyers operating from world cities to do an initial public offering or to structure a financial product in over-the-counter markets directly to institutional investors which results in cheaper credit access (Parnreiter, 2005; Schamp et al., 2004). Resultantly, APS firms are argued to be 'important influencers' of corporate decision-making, especially in the field of legal practices, financial markets and real estate markets (Parnreiter, 2010: 45). To instill investor confidence, the firm's accounts need to be reviewed by a global accountancy firm and a rating agency, the firm's strategy and organizational structure need to be advised by a management consultancy firm, and the firm needs advertisements to convince investors of their vision (Wainwright, 2012). Strategic narratives may even get the upper hand as many TNCs increasingly focus on investment in branding solely because they constitute monetized intangibles that enable augmented market capitalization (Willmott, 2010). The pursuit of shareholder value is also articulated through the adoption of corporate accounting measures 'that can offer a more persuasive reassurance to investors that a company is committed to the incorporation of value-adding, cost-squeezing disciplines into its everyday operation and restructuring' (Ezzamel et al., 2008: 109). Accounting metrics have also been adapted by APS firms themselves as law firms, for instance, have evolved from providers of fiduciary services to mega institutions with a business-oriented outlook and very high fee-based profits (Faulconbridge and Muzio, 2009). In general, in order to optimize firm performance TNC management needs to be tuned in to the world of financial analysts to deliver to 'expectations of the market' (O'Neill, 2006) and 'fit' into the mediascape of global finance (Clark et al., 2004). This requires sufficient size and acquaintance with the latest fads and fashions in strategic 
consultancy (Bryson, 2000; Froud et al., 2006). For the M' moment, in turn, optimizing and 'multiplying' the surplus becomes prominent. This explains why firms hire expensive law firms to optimize the legal structure of the firm as to maximize transfer price profits, or hire investment bankers to set up off-balance sheet special purpose vehicles in offshore centers and other tax havens in order to optimize profits through (Roberts, 1995; Wójcik, 2013b). Beyond that, they may gain advice by investment bankers as to secure and optimize income flows through allocation of the surplus into a range of financial products themselves as a hedging strategy. For example, firms whose business correlates with weather conditions will buy weather derivatives (Pike and Pollard, 2010), while oil-producing and oil-consuming industries use oil derivatives as a hedging and accumulation strategy (Labban, 2010).

Drawing on such recurring services to productive space, APS firms gradually construct 'memory banks' (Harvey, 2014: 100) of knowledge regarding firms, economic sectors, and whole economic geographies, granting them overview over the world economy and possibilities for surplus generation, which their individual clients lack (Bryson et al., 2004; Moulaert and Djellal, 1995; Sassen, 1991 [2001]). Learning within the APS complex can be understood as occurring in consecutive project ecologies at the interface between the project and the organizations, communities, and (personal) networks, where knowledge involve 'economies of recombination' as solutions are 'bricolaged' from recombinations of previous experiences by the investment bankers, lawyers, brokers, analysts, management consultants and others involved (Grabher, 2004). Financializing corporations are necessitated to shop at these APS firms to pursue economic and financial optimization to beat the average rate of return of what financial analysts consider their main competitors (Froud et al. 2006; cf. Bichler and Nitzan, 2004). Financialized firms hence increasingly rely on knowledge produced in elements II and III to inform investment 
decisions and leverage their 'solid' revenues as collateral in financial optimization of profits (Leyshon and Thrift, 2007). In sum, the APS complex acts as a gatekeeper of an enormous stock of sought-after knowledge that ultimately rests on the monopolization of knowledge out of previous fee-based interactions.

Second, the fruits of the APS monopoly position are not only direct service fees, but their global and up-to-date stock of knowledge constitutes an important ingredient in the process of the construction of (seemingly) competitive and market-beating new investment opportunities. Folkman et al. (2007) attach two roles to market intermediaries like APS. In the first instance APS can be considered what they call 'responsive functionaries' that do routine market intermediation. The by now routine work at the M and M' moment in the previous section can be categorized as such. However, in the second instance, APS can also be considered 'proactive initiators' whose highly remunerated fee-based work entails the innovation of new products. The continuous routine interaction with the productive space generates knowledge on the materialities - read economic geographies - that are a necessary element for the social construction of new circuits of value that together constitute financial geographies (Lee, 2002, 2011). Such new circuits of value can be produced via the 'innovation' of new financial products and legal contracts (e.g., 'Islamic' financial products, see Bassens et al., 2013b), often in tandem with the construction of new markets for investment altogether.

'Emerging markets' are arguably the best-documented example showing the growth of dedicated emerging market funds or similar in-house activities at investment banks since the 1990s at least (Lai, 2006; Lee, 2002; Sidaway and Bryson, 2002; Sidaway and Pryke, 2000). This is collective work in 'applied economic geography' done by a class of professional 
transnational service workers (Lee 2002) employed throughout the APS complex. Knowledge on markets is not constructed from the boardroom of these corporations in a top down fashion (Jones, 2002, 2003). Rather, as cultural-political economy perspectives have started to disclose (Hall, 2009; Jones, 2002; Thrift and Leyshon, 1994), reaching the boardrooms' strategic aims for accumulation depends on decentered and more spatially dispersed knowledge production systems. The 'imagineering' of emerging markets entails drawing on a variety of personal and impersonal data sources on companies and economies to enable investment (Lai, 2006). Project ecologies are often stretched over space as for example London-based fund managers depend on Singaporean brokers and analysts who hold knowledge on Asian economic geographies (cf. Faulconbridge, 2007). Nevertheless, the obligatory passage of APS project ecologies through WCA nodes is still fundamental in the 'emergence' of new markets. In the case of carbon emission markets, law firms often draw on previous underwriting expertise to mold and adapt contracts and develop new markets, illustrating that innovation primarily draws on knowledge transfer into new areas, rather than the innovation of entirely new markets and products per se (Knox-Hayes, 2009). The resulting financial products that provide entry-points to newly constructed circuits of value, often promise a reliable rate of return and are in large demand, especially under conditions of overaccumulation when profitable investment opportunities increasingly grow scarce. The huge and growing amounts of money capital in pension funds and sovereign wealth funds, respectively estimated at US\$27.5 trillion and US\$ 5 trillion that circulate throughout financial space explains the continuous need for further market innovation (Clark, 2003; Dixon and Monk, 2014). In such a context, the APS complex, and investment bankers, lawyers and analysts in particular, are deemed more apt than their clients in identifying investment opportunities with a reliable rate of return and hence extract fees from institutional investors desperate to fulfill the obligations to their clients (Clark and 
Monk, 2013), even though in some particular cases asset management functions are being insourced (Dixon and Monk, 2014).

Third, the gatekeeping role with regard to access to profitable investment channels is not a static affair, but hinges crucially on the permanent search for the most profitable channel offering the best return-on-investment for end-investors. Under conditions of overaccumulation, competition between investors hence drives the process of constant capital switching (Harvey, 1978, 1982 [2006], 1985; Krätke, 2014) between various existing and newly constructed circuits of value. Harvey defines switching as macro processes whereby capital shifts between production, the built environment, and reproductive functions. Switching, however, can also be understood as the practices on the micro- or meso-scale that enable the non-frictionless pouring of money in or out of a range of investment channels. The use of APS becomes obligatory since increased competition for scarce 'safe and profitable investments' renders knowledge on where and how financial capital can realize itself most profitably necessary. APS are likely to hold knowledge of the existing circuits of value they co-produced (i.e. the financial products and markets) and the underlying production space they have advised (i.e. the economic and financial operations of firms). Preferential access to knowledge about political or financial movements in emerging markets will offer a premium. Likewise, as is relevant in the fund industry (Sidaway and Bryson, 2002), close monitoring of firms in a portfolio will allow the construction of superior knowledge on the risks and opportunities associated with various investment decisions. Hence, superior knowledge on opaque non-standard products (Clark and O'Connor, 1998) refers to the ability to competitively combine various investment outlets, provide hedging strategies to cover market movements, and switch according to the need of the moment (cf. Leyshon and Thrift, 2007). 
Capital switching is a fee-based business we most directly associate with the activities of asset management services or the (hedge) fund industry (Holmes, 2009), but it can more generally refer to all legal, financial, accountancy, and other professional services catering to capital that is channeled through financial markets in search for the highest profit. Sovereign wealth funds (SWFs), for instance, are moving out of plain government bond investments and increasingly invest in equities, commodities, and real estate (Clark et al., 2010). APS firms have responded by establishing offices to maintain good face-to-face relations with SWFs in their home financial center. This also generates business in a relational way: SWF investments in London and New York have increased, while the need for expertise available in mainstay financial centers like London has received a considerable boost because of overseas deals (Bassens et al., 2013b). Pension funds are another type of actors that are increasingly pouring money into private equity and venture capital funds, most of which are as well are strongly drawn towards the knowledge circulating in world cities (Klagge and Peter, 2011; Martin et al., 2002; Robertson, 2009). The attraction lies in the very high returns on investment $-30 \%$ and over is no exception (Robertson, 2009) - even though hefty fees are paid to the managers of those funds. As spinoffs of existing financial institutions, venture capital funds strongly cluster in mainstay world cities to get access to pools of knowledge, expertise, business services, and concentrations of potential investors in those agglomerations (Martin et al., 2002). Proximity to local stock exchanges and close social networks between venture capitalists and other financiers may - if switching is required - also facilitate a potential exit from venture capital investments, for instance by doing an Initial Public Offering (IPO). Since what Martin et al. (2002: 136) call 'urban-financial centers' are likely to be the major sources of venture finance, their hands-on nature explains why most investments end up in those centers themselves and their immediate 
surrounding or neighboring regions. The geographical organization of venture capital can also be more complex. In Germany, Klagge and Peter (2011) observe a division of labor between regional centers where local knowledge about deals originates and due diligence is performed, and (inter)national centers like Frankfurt, Munich, and London where expertise about placement and financial markets can be tapped. Intriguingly enough, capital switching has also become a growing service towards high net worth individuals (HNWI), many of whom are employed as high-salaried workers in the APS complex in world cities (Beaverstock et al., 2013). Their overrepresentation in world cities and the concentration of asset management expertise explains why private wealth management services in banking, law and accountancy are again mostly provided from key world cities (and London in particular). In some cases traditional advice on IPOs and Mergers \& Acquisitions are reformulated as advice by wealth management arms of investment banks to the HNWI who own shares in their company as to how to benefit the most from the imminent deal. The creation of new circuits of value for businesses can hence simultaneously be the feedstock for capital switching activities of their managers.

\section{Consuming the monopoly: Finance feeding upon itself}

It might be argued that the notion of the APS complex as a class monopoly falls apart in the face of the global financial crisis of 2008 (Smith, 2014). In our view, the recurrence of such major crises is indicative of the ability of a group of actors that is structurally dominant in circuits of value to engage in practices that involve high-risk taking. Pre-crisis, but also post-crisis practices in many world cities indicate indeed that APS are far more than just the neutral operator of a now financialized global economy, but rather a consumer proper of that preferential knowledge as part of an accumulation strategy during intense global competition within the APS complex. This is most evident in the financial services industry where retail and 
investment banks alike have continuously reinvented themselves as financial service providers over the past few decades, focusing on new activities that increasingly depend on fee income (Erturk and Solari, 2007). Competition within the financial services section of the APS complex has urged institutions to participate in the very casino practices they supposedly controlled (Froud et al., 2012; Strange, 1988 [1994]). We cannot possibly go into too much detail about this matter here (see Christophers, 2009; Engelen et al., 2011), but we do need to clarify three mechanisms by which the APS complex have and are jeopardizing their class monopoly position which paradoxically results in even stronger agglomeration in world cities in general and IFCs in particular.

The first reinforcing mechanism results from the necessity to tap into the knowledge flows inside the WCA to produce the range of complex securitized products, derivatives, and other structured finance products that yield high profits for the financial sector and its auxiliary services (Engelen et al., 2010a). This was especially shown to be the case in the US and UK economies and involved most prominently - but was certainly not limited to - financial institutions in onshore-offshore zones in New York and London (Wójcik, 2013a). The fall of Lehman Brothers revealed that also continental European financial institutions were strongly involved as buyers or even 'innovators' of such structured finance products in a murky shadow banking system (Bassens et al., 2013a; Engelen et al., 2010b). The looming situation of overaccumulation explains why there was such a demand for these assets deemed safe but turned toxic.

A second reinforcing mechanism involves the now increasingly common practice of proprietary trading at many large financial institutions (Wójcik, 2012). Briefly put, this refers to the use of 
own capital - instead of the funds provided by customers - for profit making market operations. Financial institutions are for a growing part reliant on the profit made by short-term investing and trading in financial products such as stocks, bonds, derivatives, etc. (Crotty, 2007). In these respects, banks behave similarly to hedge funds and take-on leveraged positions based on borrowed money in order to compete in a globalized financial sector. Moreover, investment banks are notorious to take many and often conflicting positions vis-à-vis their clients, acting simultaneously as analysts, lenders, underwriters, asset managers, and proprietary traders of the client's shares (Ertürk and Solari, 2007: 385). This implies that the knowledge sold to endinvestors was and is also marshaled to restructure the corporate organization and to financially and legally optimize financial institutions themselves to construct new circuits of value and to make investments and switch capital for the sake of financial institutions' market position. This development was spurred on by the growing demand for high returns on investment by shareholders with listed financial institutions that were increasingly fighting a global sectorial consolidation battle (Engelen et al., 2011; Jones, 2003).

Third, beyond preferential access to knowledge, there is also an absolute spatial monopoly rent (Walker, 1974) in IFCs that relates to pure technicalities as to how short-term profits are achieved. The more recent developments in prop trading involve computerized high frequency trading practices that - as the name suggest - rely on making small profits from millions of transactions per second. In this context being on the Internet backbone is fundamental for switching nearly instantaneously between hold and put positions fractions of seconds before the rest of the market. Although these practices of financial institutions are now increasingly recognized for what they are (Engelen and Glasmacher, 2013), they nevertheless continue to 
augment the relevance of the WCA space and some of its best-connected islands in particular in the long aftermath of the most recent crisis.

\section{Conclusions}

In his 1995 reflection on a decade of world cities research, John Friedmann wrote the noteworthy phrase that 'we must remember that the dynamism of the political economy of capital is so great that no single paradigm is likely to remain intact for more than a couple of decades at most. The world city hypothesis has proved useful as a theoretical framework, but the real city is swiftly changing into something else, and eternal vigilance over ongoing change processes is the price of our knowledge' (Friedmann, 1995: 35). This is the fourth decade in a row that empirical evidence points to the enduring importance for capitalism of this archipelago of highly connected urban localities (Derudder et al., 2012). Therefore, in the spirit of Friedmann's words, this paper has contributed to theorizing to what extent socio-spatial practices in world cities, which continue to produce an uneven capitalist geography, have changed in the meantime.

Before we sketch the research agenda that follows from putting financialization center stage in the (re)production of the WCA, we like to emphasize two important caveats in regard to the presentation above. First, this paper has largely bracketed the role of the state in the construction and reproduction of world cities in contemporary financialized globalization. Although the logic of state power is not coterminous with that of capital, the two are coconstitutive (Arrighi, 1994[2010]; Harvey, 2003, 2014; Jessop, 2010). We have touched upon how the deregulatory changes in the 1980s were enabled by the US government and referred to the critical literature on world cities detailing how state actors accommodate and facilitate the 
reproduction of the WCA and its main islands (Brenner, 1998; Massey, 2007; Sassen, 2006). A better understanding of the role of state actors as enablers, but also as possible resistors, of the APS class monopoly is crucial to carry world city research further. This is paramount since there are clear indications that actors within the APS complex as a fraction of capital can translate their structural dominance in economic terms into socio-political action that allow their reproduction, notwithstanding conspicuous activities prior to the crisis (Froud et al., 2012). Second, this paper has exclusively focused on developments since the 1970 s as the postBretton Woods period can arguably be considered the era when financialized globalization came about in earnest. Taking seriously this new articulation of world cities under financial globalization, however, ultimately begs the question to what extent there are continuities and discontinuities in the role of world cities in accumulation processes in the longue durée (Arrighi, 1994[2010]; Christophers, 2013; Taylor, 2011).

A core aim of this paper was to issue a call to conjoin two relatively separate research fields in human geography and to provide a metatheoretical proposal for that conjunction. Traditionally, world cities research has examined a production space that focuses on the role of APS firms in global flexible accumulation. Conversely, financial geographers have tended to study a financial space largely taking place in IFCs, in which the very same APS firms play an equally important but different role (Thrift, 1987). If the proposed augmentations to Friedmann's world city hypothesis hold, the geographies of IFCs could very well be subsumed as specialist centers in a broader concept of world cities under financialization. At various moments IFCs require knowledge of existing and newly created circuits of value running through a far more dispersed space that is tapped into via a much broader range of world cities. In any case, financialization processes challenge readings of world cities that are cast in an isolated production logic, that is 
as mere sites from where seamless service to a global economy are provided. In this paper we have therefore proposed to dissect the complete logic of accumulation under financialized globalization from initial capital attraction in the production circuit to the optimization of the surplus in an integrated manner. This has made us argue that the contemporary inevitability of WCA space arises from the three synergistic knowledge-based activities of APS: their delivery of 'advanced' services to financialized TNCs, the construction of new circuits of value, and the service of capital switching in search for the most profitable circuit. We can certainly have our doubts about the nature of that knowledge, as the credibility and reputation of APS often depends on self-boosted images of professionalism and expertise. Yet, following from our argument, we can theorize how that knowledge may actually come about out of previous APS client iterations, and how it potentially disseminates into adjoining areas of advanced servicing. The crisis of 2008 has questioned much of the wisdom of (segments of) the APS complex, but the rapid rebound in their activities since then indicates that structural conditions of overaccumulation are such that convincing stories about their aid in profit-maximization strategies is eagerly bought by a variety of state- and market-based actors.

This thesis is explicitly proposed as a starting point for deepened investigation. Nuancing, corroborating or refuting the above claims could further our collective understanding of the centrality of the WCA in contemporary capitalism in general and its role in the enduring crisis in particular. This is as much a project of bringing into dialogue already existing insights from various research communities interested in service industries, global production networks, financial geographies, knowledge geographies, and many more, as it is a matter of opening new lines of inquiry. The challenges, but also the potential answers, lie in bringing such insights together in one analytical framework. In practice, we need a more thorough understanding of 
the geographies and power relations embedded in the 'knowledge value chain' that connect the three elements in the WCA class monopoly we identified above. Four issues are of particular relevance: First, how exactly does knowledge travel through the WCA space? What kinds of knowledge obtained from one element end up in the others? And who are the actors that facilitate the transfers within the chain? How is this knowledge transfer discursively and practically articulated by the actors conducting it? Second, we need to establish how advanced servicing, the social production of circuits of value, and capital switching take place in the archipelago. What are the social and spatial divisions of labor that support these three kinds of activities? To what extent do these three geographies overlap or diverge? Third, what kind of power relations and modalities underlie these interactions within the APS complex (Allen, 2003) and what is the exact role of competition between firms in its articulation? How do power asymmetries between the APS complex and their counterparties emerge and endure? Fourth and finally, we should investigate how those power relations play out spatially at the level of temporary relations between individual actors and firms, but also at the macro level, where more long-lasting power asymmetries may result in core-periphery structures. Answering these questions will obviously necessitate the inclusion of different methods of measuring and mapping those geographies, whereby a spatial analysis of project ecologies can be considered a fruitful avenue, as is a renewed emphasis on qualitative research of world city networks (Watson and Beaverstock, 2014).

To end, detailed knowledge on the socio-spatial workings of the WCA, for instance in areas like tax offshoring, may ultimately serve to provide a fuller picture of contemporary capitalism. Competition within the APS complex played an important role in shaping the financial crisis of 2008 when finance was exposed to feed on itself. This was a typical case where holders of a 
class monopoly acted against its own class interest by endangering the class monopoly position. Nevertheless, we observe that this class monopoly has largely been reconstituted despite the endurance of the crisis. The question why societies over the world have let this happen is one of the most paramount today. Based on the mechanisms elucidated above there seems a clear connection with the addiction to regular high-level interest-based profits for collective institutions such as pension funds, and the fact that accommodating the activities of the APS complex are often an important growth regime for restructuring states (Massey, 2007). If we do not want history to repeat itself with a vengeance, this interface in particular should remain a central point of study. The evidence brought together in this paper indicates that APS are neither the new source of benign post-industrial or post-fordist growth, nor just the quintessential producers of knowledge on surplus creation in a financialized and globalized and hence uncertain world. Rather, if the augmented world city hypothesis holds, it seems that the WCA serves as a space for the fee-incurring APS complex to run the casino of financial capitalism. That is: to win at every turn irrespective of the outcome, instead of participating in it as a docile gamer.

\section{Acknowledgements}

We thank the editors and the anonymous referees of Progress in Human Geography for sharpening our argument. Furthermore, we would like to thank Ben Derudder and Pieter Saey for the constructive dialogue during the genesis of the paper. Earlier versions of this paper were presented on conferences in London (RGS-IBG), Passau (Deutscher Geographentag), Loughborough (ARL Summer School) and Leuven (REFCOM seminar) and we would like to acknowledge the feedback given there. The authors are listed in alphabetical order, but share equal responsibility for the paper's content and any remaining errors. 


\section{References}

Aalbers MB (2009) Geographies of the financial crisis. Area 41: 34-42.

Allen J (2003) Lost Geographies of Power. Malden: Blackwell Publishing.

Allen J (2010) Powerful city networks: More than connections, less than domination and control. Urban Studies 47: 2895-2911.

Amin A and Thrift NJ (1992) Neo-Marshallian nodes in global networks. International Journal of Urban and Regional Research 16: 571-587.

Arrighi G (1994 [2010]) The Long Twentieth Century. Money, Power and the Origins of Our Times. London / New York: Verso.

Asheim BT, Coenen L, and Vang J (2007) Face-to-face, buzz, and knowledge bases: Sociospatial implications for learning, innovation, and innovation policy. Environment and Planning C: Government and Policy 25: 655-670.

Baaij M, van den Bosch F, and Volberda H (2004) The international relocation of corporate centres. European Management Journal 22: 141-149.

Bassens D, Derudder B, and Witlox F (2010) Searching for the Mecca of finance: Islamic financial services and the world city network. Area 42 : 35-46.

Bassens D, van Meeteren M, Derudder B, and Witlox F (2013a) No more credit to Europe? Cross-border bank lending, financial integration, and the rebirth of the national scale as a credit scorecard. Environment and Planning A 45: 2399-2419.

Bassens D, Engelen E, Derudder B, and Witlox F (2013b) Securitization across borders: Organizational mimicry in Islamic finance. Journal of Economic Geography 13: 85-106.

Beaverstock JV (2004) 'Managing across borders': Knowledge management and expatriation in professional service firms. Journal of Economic Geography 4: 157-179.

Beaverstock JV, Hall S, and Wainwright T (2013) Servicing the super-rich: New financial elites 
and the rise of the private wealth management retail ecology. Regional Studies 47: 834849.

Beaverstock JV, Smith RG, and Taylor PJ (2000) World-city network: A new metageography? Annals of the Association of American Geographers 90: 123-134.

Bell D (1973) The Coming of Post-Industrial Society: A Venture in Social Forecasting. New York: Basic Books.

Berndt C and Boeckler M (2010) Geographies of markets: Materials, morals and monsters in motion. Progress in Human Geography 35: 559-567.

Bichler S and Nitzan J (2004) Dominant capital and the new wars. Journal of World Systems Research 10: 1-37.

Boyer R (2000) Is a finance-led growth regime a viable alternative to Fordism? A preliminary analysis. Economy and Society 29: 111-145.

Braudel F (1982) The Wheels of Commerce. New York: Harper \& Row.

Brenner N (1998) Global cities, glocal states: Global city formation and state territorial restructuring in contemporary Europe. Review of International Political Economy 5: 1-37.

Bryson JR (2000) Spreading the message. Management consultants and the shaping of economic geographies in time and space. In: Bryson JR, Daniels PW and Pollard J (eds) Knowledge, Space, Economy. London and New York: Routledge, 157-175.

Bryson JR, Daniels PW, and Warf B (2004) Service Worlds: People, Organisations, Technologies. London: Routledge.

Burn G (1999) The state, the city and the euromarkets. Review of International Political Economy 6: 225-261

Callon M (1986) Some elements of a sociology of translation: Domestication of the scallops and the fishermen of St Brieuc Bay. In: Law J (ed) Power, Action and Belief: A New Sociology 
of Knowledge. London: Routledge, 196-223.

Castells M (1996 [2000]). The rise of the Network Society (2nd ed.). Cambridge MA/Oxford UK: Blackwell Publishing.

Castree N (1999) Envisioning capitalism: Geography and the renewal of Marxian political economy. Transactions of the Institute of British Geographers 24: 137-158.

Christophers B (2009) Complexity, finance, and progress in human geography. Progress in Human Geography 33: 807-824.

Christophers B (2013) Banking Across Boundaries. Placing Finance in Capitalism. Hoboken: Wiley Blackwell.

Clark GL (2003) Pension security in the global economy: Markets and national institutions in the 21st century. Environment and Planning A 35: 1339-1356.

Clark GL (2005) Money flows like mercury: The geography of global finance. Geografiska Annaler: Series B 87: 99-112.

Clark GL, Monk AHB, Dixon A, et al. (2010). Symposium: Sovereign fund capitalism. Environment and Planning A 42: 2271-2291.

Clark GL and Monk AHB (2013) The scope of financial institutions: In-sourcing, outsourcing and off-shoring. Journal of Economic Geography 13: 279-298.

Clark GL and O'Connor K (1997) The informational content of financial products and the spatial structure of the global finance industry. In: Cox KR (ed.) Spaces of Globalization: Reasserting the Power of the Local. New York: The Guilford Press, 89-115.

Clark GL, Thrift NJ, and Tickell A (2004) Performing finance: The industry, the media and its image. Review of International Political Economy 11: 289-310.

Coe NM, Lai K, and Wójcik D (2014) Integrating finance into global production networks. Regional Studies 48: 761-777. 
Coffey WJ and Bailly AS (1990) Service activities and the evolution of production systems: An international comparison. Environment and Planning A 22: 1607-1620.

Cohen RB (1981) The new international division of labour, multi-national corporations and urban hierarchy. In: Dear MJ and Scott AJ (eds) Urbanization and Urban Planning in Capitalist Society. New York: Methuen, 287-315.

Crotty $\mathrm{J}$ (2008) If financial market competition is intense, why are financial firm profits so high? Reflections on the current "golden age" of finance. Competition and Change 12, 167-183. Daniels PW and Moulaert F (eds) (1991) The Changing Geography of Advanced Producer Services. London/New York: Belhaven Press.

Derudder B, Hoyler M, and Taylor PJ (2011) Goodbye Reykjavik: International banking centres and the global financial crisis. Area 43: 173-182.

Derudder B, Taylor PJ, Ni P, et al. (2010) Pathways of change: Shifting connectivities in the world city network, 2000—08. Urban Studies 47: 1861-1877.

Derudder B, Hoyler M. Taylor PJ and Witlox F (eds) (2012) The International Handbook of Globalization and World Cities. Cheltenham: Edward Elgar.

DiMaggio P and Powell WW (1983) The iron cage revisited: Institutional isomorphism and collective rationality in organizational fields. American Sociological Review 48: 147-160.

Dixon AD and Monk AHB (2014) Frontier finance. Annals of the Association of American Geographers 104: 852-868.

Engelen E (2008) The case for financialization. Competition and Change 12: 111-119.

Engelen E and Faulconbridge JR (2009) Introduction: Financial geographies-the credit crisis as an opportunity to catch economic geography's next boat? Journal of Economic Geography 9: 587-595.

Engelen E and Glasmacher A (2013) Multiple financial modernities. International financial 
centres, urban boosters and the Internet as the site of negotiations. Regional Studies 47: $850-867$.

Engelen E, Erturk I, Froud J, et al. (2010a) Reconceptualizing financial innovation: Frame, conjuncture and bricolage. Economy and Society 39: 33-63.

Engelen E, Konings M and Fernandez R (2010b) Geographies of financialization in disarray, the Dutch case in comparative perspective. Economic Geography 86: 53-73.

Engelen E, Erturk I, Froud J, et al. (2011) After the Great Complacence. Financial Crisis and the Politics of Reform. Oxford: Oxford University Press.

Epstein GA (ed) (2005) Financialization and the World Economy. Cheltenham: Edward Elgar.

Erturk I and Solari S (2007) Banks as continuous reinvention. New Political Economy, 12: 369388.

Ezzamel M, Willmott $\mathrm{H}$ and Worthington $\mathrm{F}$ (2008) Manufacturing shareholder value: The role of accounting in organizational transformation. Accounting, Organizations and Society 33: $107-140$.

Faulconbridge JR (2007) Relational knowledge networks in transnational law firms. Geoforum 38: 925-940.

Faulconbridge JR and Muzio D (2009) The financialization of large law firms: Situated discourses and practices of reorganization. Journal of Economic Geography 9: 641-661.

Fligstein N (2001) The Architecture of Markets: An Economic Sociology of Twenty-First-Century Capitalist Societies. Princeton NJ: Princeton University Press.

Folkman P, Froud J, Johal S and Williams K (2007) Working for themselves? Capital market intermediaries and present day capitalism. Business History 49: 552-572.

French S, Leyshon A, and Thrift NJ (2009) A very geographical crisis: The making and breaking of the 2007-2008 financial crisis. Cambridge Journal of Regions, Economy and Society 2: 
287-302.

French S, Leyshon A, and Wainwright T (2011) Financializing space, spacing financialization. Progress in Human Geography 35: 798-819.

Friedmann J (1986) The world city hypothesis. Development and Change 17: 69-83.

Friedmann J (1995) Where we stand: A decade of world cities research. In: Knox PL and Taylor PJ (eds) World Cities in a World System. Cambridge: Cambridge University Press, 2148.

Friedmann J and Wolff G (1982) World city formation: An agenda for research and action. International Journal of Urban and Regional Research 6: 309-344.

Fröbel F, Heinrichs J and Kreye O (1977 [1980]) The New International Division of Labour. Cambridge: Cambridge University Press.

Froud J, Haslam C, Johal S and Williams K (2000) Shareholder value and financialization: Consultancy promises, management moves. Economy and Society 29: 80-110.

Froud J, Johal S, Leaver A and Williams K (2006) Financialization and Strategy: Narrative and Numbers. Abingdon / New York: Routledge.

Froud J, Nilsson A, Moran, M and Williams K (2012) Stories and interests in finance: Agendas of governance before and after the financial crisis. Governance 25: 35-59.

Grabher G (2004) Learning in projects, remembering in networks? Communality, sociality, and connectivity in project ecologies. European Urban and Regional Studies 11: 103-123.

Hall S (2006) What counts? Exploring the production of quantitative financial narratives in London's corporate finance industry. Journal of Economic Geography 6: 661-678.

Hall S (2009) Ecologies of business education and the geographies of knowledge. Progress in Human Geography 33: 599-618.

Hall S (2012) Geographies of money and finance II. Progress in Human Geography 36: 403- 
411.

Harvey D (1974) Class-monopoly rent, finance capital and the urban revolution. Regional Studies 8: 239-255.

Harvey D (1978) The urban process under capitalism: A framework of analysis. International Journal of Urban and Regional Research 2: 101-131.

Harvey D (1982 [2006]) The Limits to Capital (2nd ed). London / New York: Verso.

Harvey D (1985) The Urbanization of Capital. Oxford: Basil Blackwell.

Harvey D (2003) The New Imperialism. Oxford: Oxford University Press.

Harvey D (2005 [2006]). Spaces of Global Capitalism. London / New York: Verso.

Harvey D (2010) The Enigma of Capital and the Crises of Capitalism. London: Profile Books.

Harvey D (2014) Seventeen Contradictions and the End of Capitalism. London: Profile Books.

Harvey D and Chatterjee L (1974) Absolute rent and the structuring of space by governmental and financial Institutions. Antipode 6: 22-36.

Henderson J and Castells M (eds) (1987) Global Restructuring and Territorial Development. London / Beverly Hills / New Delhi: Sage.

Henderson J, Dicken P, Hess M, et al. (2002) Global production networks and the analysis of economic development. Review of International Political Economy 9: 436-464.

Holmes C (2009) Seeking alpha or creating beta? Charting the rise of hedge fund-based financial ecosystems'. New Political Economy 14: 431 - 450.

Hymer S (1972) The multinational corporation and the law of uneven development. In: Bhagwati JN (ed) Economics and World Order from the 1970s to the 1990s. New York: Macmillian: 113-141.

Jessop B (2000) The crisis of the national spatio-temporal fix and the tendential ecological dominance of globalizing capitalism. International Journal of Urban and Regional 
Research 24: 323-360.

Jones A (2002) The 'global city' misconceived: The myth of 'global management' in transnational service firms. Geoforum 33: 335-350.

Jones A (2003) Management Consultancy and Banking in an era of Globalisation. Basingstoke: Macmillian.

Jones A (2008) Beyond embeddedness: Economic practices and the invisible dimensions of transnational business activity. Progress in Human Geography 32: 71-88.

Klagge B and Peter C (2011) Changes in the German urban system-A financial-sector perspective. Raumforschung und Raumordnung 69: 201-211.

Knox-Hayes J (2009) The developing carbon financial service industry: Expertise, adaptation and complementarity in London and New York. Journal of Economic Geography 9: 749777.

Knox PL and Taylor PJ (Eds) (1995) World Cities in a World System. Cambridge: Cambridge University Press.

Krätke S (2014) Cities in contemporary capitalism. International Journal of Urban and Regional Research. DOI:10.1111/1468-2427.12165

Krippner GR (2011) Capitalizing on Crisis. The Political Origins of the Rise of Finance. Cambridge MA / London: Harvard University Press.

Labban M (2010) Oil in parallax: Scarcity, markets, and the financialization of accumulation. Geoforum, 41: 541-552.

Lai K (2006) "Imagineering" Asian emerging markets: Financial knowledge networks in the fund management industry. Geoforum 37: 627-642.

Lai K (2012) Differentiated markets: Shanghai, Beijing and Hong Kong in China's financial centre network. Urban Studies 49: 1275-1296. 
Lee R (1989) Social relations and the geography of material life. In: Gregory D and Walford R (eds) Horizons in Human Geography. Basingstoke: Macmillian, 152-169.

Lee R (2002) "Nice maps, shame about the theory?" Thinking geographically about the economic. Progress in Human Geography 26: 333-355.

Lee R (2006) The ordinary economy: Tangled up in values and geography. Transactions of the Institute of British Geographers NS 31: 413-432.

Lee R (2011) Spaces of hegemony? Circuits of value, finance capital and places of financial knowledge. In: Agnew J and Livingstone DN (eds) The SAGE handbook of Geographical Knowledge. London / Thousand Oaks / New Delhi: Sage, 183-199.

Lee R, Clark GL, Pollard J and Leyshon A (2009) The remit of financial geography-before and after the crisis. Journal of Economic Geography 9: 723-747.

Lewis MW and Wigen KE (1997) The Myth of Continents: A Critique of Metageography. Berkeley: University of California Press.

Leyshon A and Thrift NJ (2007) The capitalization of almost everything: The future of finance and capitalism. Theory, Culture \& Society 24:97-115.

Lizieri C (2011) Global cities, office markets and capital flows. In: Derudder B, Hoyler M, et al. (eds) International Handbook of Globalization and World Cities. Cheltenham: Edward Elgar, 162-176.

Mandel E (1972 [1975]) Late Capitalism. London: NLB.

Martin R, Sunley P and Turner D (2002) Taking risks in regions: The geographical anatomy of Europe's emerging venture capital market. Journal of Economic Geography 2: 121-150.

Marx K (1867 [1976]) Capital, Volume 1. London: Penguin Books.

Marx K (1885 [1992]) Capital, Volume 2. London: Penguin Books.

Marx K (1894 [1991]) Capital, Volume 3. London: Penguin Books. 
Massey D (1984 [1995]) Spatial Divisions of Labour. Social Structures and the Geography of Production (2nd ed.). Basingstoke: Macmillian Press.

Massey D (2007) World City. Cambridge UK: Polity Press.

Morgan G (2001) Transnational communities and business systems. Global Networks 1: 113130.

Morgan G and Quack S (2006) The internationalisation of professional service firms: Global convergence, national path-dependency or cross-border hybridisation? In: Suddaby R and Greenwood R (eds) Professional Service Firms. Bingley: Emerald Publishing, 403431.

Moulaert F and Djellal F (1995) Information technology consultancy firms: Economies of agglomeration from a wide-area perspective. Urban Studies 32: 105-122.

Moulaert F, Scott AJ and Farcy H (1997) Producer services and the formation of urban space. In: Moulaert F and Scott AJ (eds), Cities, Enterprises and Society on the eve of the 21st Century. London and Washington: Pinter, 97-112.

Muellerleile CM (2009) Financialization takes off at Boeing. Journal of Economic Geography 9: $663-677$.

Olds K and Yeung HW-C (2004) Pathways to global city formation: A view from the developmental city-state of Singapore. Review of International Political Economy 11: 489-521.

O'Neill P (2001) Financial narratives of the modern corporation. Journal of Economic Geography 1: 181-199.

O'Neill P (2006) The corporation, shareholder value added, and the power of financial management narratives. In: Taylor M and Oinas P (eds) Understanding the Firm. Spatial and Organizational Dimensions. Oxford: Oxford University Press, 87-117. 
Parnreiter C (2005) "The world's local bank": Finanzdienstleiter, globale güterketten und das world city network. Mitteilungen der Österreichischen Geographischen Gesellschaft 147: $37-66$.

Parnreiter C (2010) Global cities in global commodity chains: Exploring the role of Mexico City in the geography of global economic governance. Global Networks 10: 35-53.

Parnreiter C (2013) The global city tradition: Origins, advancements, merits, deflections, shortcomings and challenges. In: Acuto M and Steele W (eds) Global City Challenges. Debating a Concept, Improving the Practice. Basingstoke: Palgrave Macmillan, 15-32.

Parnreiter C (2014) Network or hierarchical relations? A plea for redirecting attention to the control functions of global cities. Tijdschrift voor Economische en Sociale Geografie 105: 398-411.

Pike A and Pollard J (2010) Economic geographies of financialization. Economic Geography 86: $29-51$.

Pryke M and Lee R (1995) Place your bets: Towards an understanding of globalisation, sociofinancial engineering and competition within a financial centre. Urban Studies, 32: 329344.

Roberts SM (1995) Small place, big money: The Cayman Islands and the international financial system. Economic Geography 71: 237-256.

Robertson J (2009) Private equity funds. New Political economy 14: 545-555.

Rodrigues MJ (ed.) (2002) The New Knowledge Economy in Europe. A Strategy for International Competitiveness and Social Cohesion. Cheltenham: Edward Elgar.

Ross RJS and Trachte KC (1983) Global cities and global classes: The peripheralization of labor in New York City. Review (Fernand Braudel Center) 6: 393-431.

Ross RJS and Trachte KC (1990) Global Capitalism: The New Leviathan. New York: State 
University of New York Press.

Saey P (2007) How cities scientifically (do not) exist: Methodological appraisal of research on globalizing processes of intercity networking. In: Taylor PJ, Derudder B, et al. (eds) Cities in Globalization. Practices, policies and theories. London / New York: Routledge, 286301.

Sassen-Koob S (1982) Recomposition and Peripheralization at the Core. Contemporary Marxism 5: 88-100.

Sassen-Koob S (1985) Capital mobility and labor migration: Their expression in core cities. In: Timberlake M (ed) Urbanization in the World-Economy. Orlando : Academic Press, 231265.

Sassen S (1988) The Mobility of Labor and Capital. Cambridge: Cambridge University Press.

Sassen S (1991 [2001]) The Global City. Princeton: Princeton University Press.

Sassen S (1998) Swirling that old wine around in the wrong bottle: a comment on White. Urban Affairs Review 33: 478-481.

Sassen S (2006) Territory, Authority, Rights: From Medieval to Global Assemblages. Princeton: Princeton University Press.

Sassen S (2010) A savage sorting of winners and losers: Contemporary versions of primitive accumulation. Globalizations 7: 23-50.

Saxenian A (1996) Regional Advantage: Culture and Competition in Silicon Valley and Route 128. Cambridge MA: Harvard University Press.

Saxenian A (2007) The New Argonauts: Regional Advantage in a Global Economy. Cambridge MA: Harvard University Press.

Schamp EW, Rentmeister B and Lo V (2004) Dimensions of proximity in knowledge-based networks: The cases of investment banking and automobile design. European Planning 
Studies 12: 607-624.

Schoenberger E (1997) The Cultural Crisis of the Firm. Cambridge MA / Oxford: Blackwell.

Schumpeter J (1928) The instability of capitalism. The Economic Journal 38: 361-386.

Scott AJ (1998) Regions and the World Economy. New York: Oxford University Press.

Scott AJ (2012) A World In Emergence. Cheltenham/Northampton: Edward Elgar.

Sidaway JD and Bryson JR (2002) Constructing knowledges of "emerging markets": UK-based investment managers and their overseas connections. Environment and Planning A 34: 401-416.

Sidaway JD and Pryke M (2000) The strange geographies of "emerging markets." Transactions of the Institute of British Geographers NS 25: 187-201.

Smith RG (2014) Beyond the global city concept and the myth of "command and control". International Journal of Urban and Regional Research 38: 98-115.

Smith RG and Doel MA (2010) Questioning the theoretical basis of current global-city research: Structures, networks and actor-networks. International Journal of Urban and Regional Research 35, 24-39.

Soja EW, Morales R, and Wolff G (1983) Urban restructuring: An analysis of social and spatial change in Los Angeles. Economic Geography 59: 195-230.

Storper M and Walker R (1989) The Capitalist Imperative. Territory, Technology and Industrial Growth. Oxford/ New York: Basil Blackwell.

Storper M (1997) The Regional World. New York: The Guilford Press.

Strange S (1988 [1994]) States and Markets (2nd ed.). London New York: Continuum.

Surborg B (2011) World cities are just "basing points for capital": Interacting with the world city from the Global South. Urban Forum 22: 315-330.

Swyngedouw EA (1992) Territorial organization and the space/technology nexus. Transactions 
of the Institute of British Geographers NS17: 417-433.

Taylor PJ (2000) World cities and territorial states under conditions of contemporary globalization. Political Geography 19: 5-32

Taylor PJ (2004) World City Network: A Global Urban Analysis. London: Routledge.

Taylor PJ (2011) Problematizing city/state relations: Towards a geohistorical understanding of contemporary globalization. Transactions of the Institute of British Geographers NS32: $133-150$.

Thrift NJ (1987) The fixers: The urban geography of international commercial capital. In: Henderson J and Castells M (eds) Global Restructuring and Territorial Development. London/Beverly Hills/ New Delhi: Sage, 203-234.

Thrift NJ (1993) An urban impasse? Theory, Culture \& Society 10: 229-238.

Thrift NJ and Leyshon A (1988) "The gambling propensity": Banks, developing country debt exposures and the new international financial system. Geoforum 19: 55-69.

Thrift NJ and Leyshon A (1994) A phantom state? The de-traditionalization of money, the international financial system and international financial centres. Political Geography 13: 299-327.

Tickell A and Peck J (1992) Accumulation, regulation and the geographies of post-Fordism: Missing links in regulationist research. Progress in Human Geography 16: 190-218.

Wainwright T (2011) Tax doesn't have to be taxing: London's "onshore" finance industry and the fiscal spaces of a global crisis. Environment and Planning A 43: 1287-1304.

Wainwright T (2012) Number crunching: Financialization and spatial strategies of risk organization. Journal of Economic Geography 12: 1267-1291.

Walker RA (1974) Urban ground rent: Building a new conceptual framework. Antipode, 6, 5158. 
Walker RA (1985) Is there a service economy? Science \& Society 49: 42-83.

Watson A and Beaverstock JV (2014) World city network research at a theoretical impasse: On the need to re-establish qualitative approaches to understanding agency in world city networks. Tijdschrift voor Economische en Sociale Geografie 105: 412-426.

Willmott $\mathrm{H}$ (2010) Creating "value" beyond the point of production: Branding, financialization and market capitalization. Organization 17: 517-542.

Wójcik D (2012) The end of investment bank capitalism? An economic geography of financial jobs and power. Economic Geography 88: 345-368.

Wójcik D (2013a) The dark side of NY-LON: Financial centres and the global financial Crisis. Urban Studies 50: 2736-2752.

Wójcik D (2013b) Where governance fails: Advanced business services and the offshore world. Progress in Human Geography 37: 330-347. 


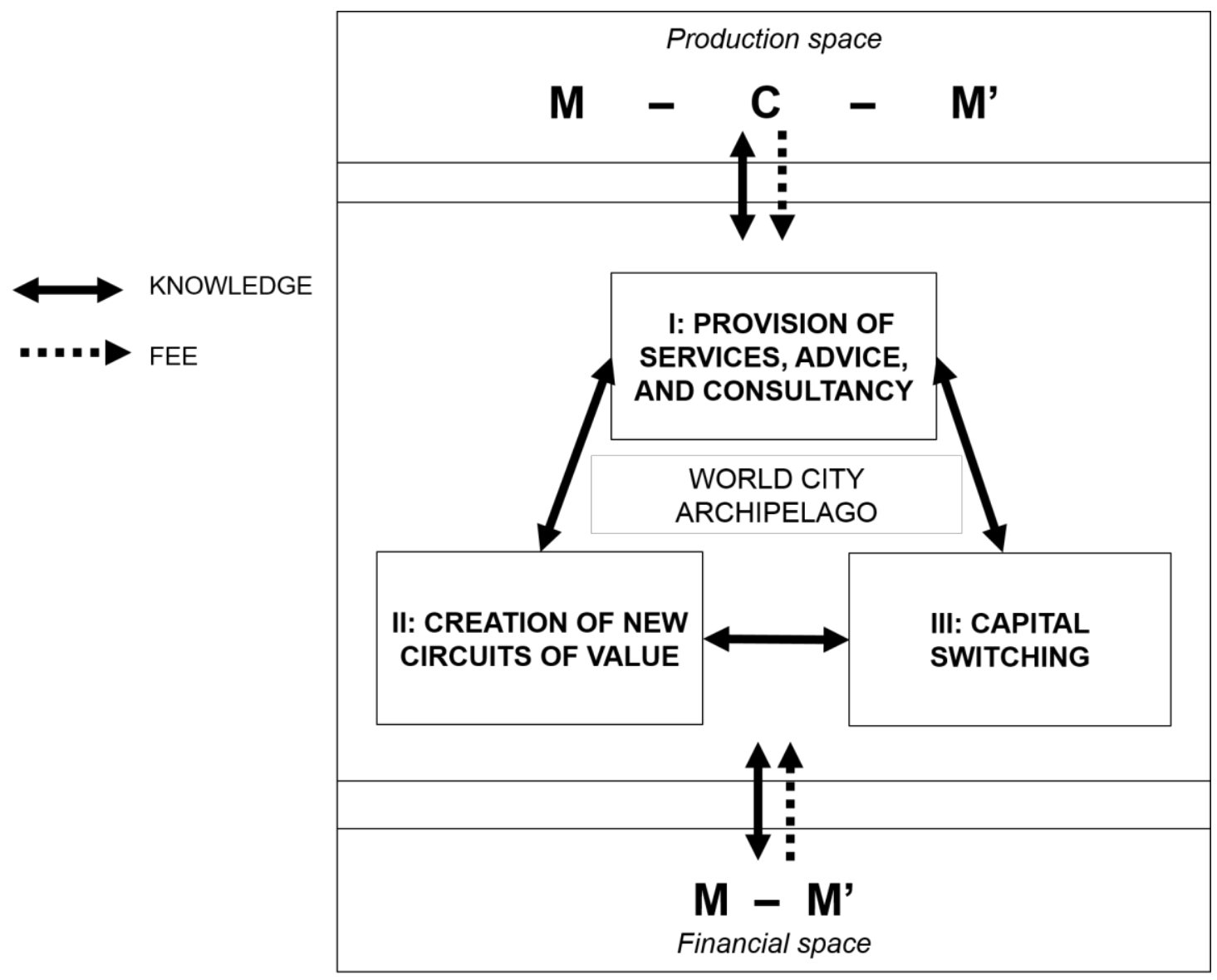

Figure $1 \mathrm{~A}$ conceptual overview of the elements driving world city archipelago formation 


\begin{abstract}
' Hymer (1972) already discusses the geographic centralization of corporate decision-making power. To our knowledge, the oldest reference to the literal phrase 'command and control functions of the world economy' is made by Ross and Trachte (1983: 395) who directly paraphrase and criticize Hymer. The coining of the literal phrase is often incorrectly attributed to Sassen (1991)[2001] or Friedmann (1986) who use related concepts such as 'global control capability' (Sassen-Koob, 1985; Sassen, 1991[2001]: 6-7), 'global control function' (Friedmann, 1986: 69), or 'worldwide system of control' (Friedmann and Wolff, 1982: 310).
\end{abstract}

ii The concept of 'class monopoly rent' was originally developed in the context of housing studies and urban land competition (Harvey and Chatterjee, 1974; Harvey, 1974). The logic is fully transposable to the knowledge scarcity on capital realization in the context of the APS complex (cf. Swyngedouw 1992). 